\title{
Meat Quality of Land Crab, Cardiosoma armatum (Herklots, 1851) Fattened with Trash Fish and Formulated Diet
}

\author{
G. Oluwole ${ }^{1}$, R. O. Moruf $^{\mathbf{f}^{*}}$, A. O. Lawal-Are ${ }^{1}$ \\ ${ }^{1}$ Department of Marine Sciences, University of Lagos, Akoka, Lagos State- Nigeria \\ ${ }^{2}$ Department of Fisheries and Aquaculture, Bayero University, Kano, Kano State- Nigeria \\ Received 21 November 2019, accepted in final revised form 27 February 2020
}

\begin{abstract}
Meat quality in terms of its nutritional value, is a major factor when considering dietary items. This study highlighted the proximate and mineral compositions in the meat of Land Crab, Cardiosoma armatum (Herklots, 1851) fed with Trash Fish (Natural feed) and formulated diet for three (3) months. The meat proximate composition of both crabs fed the two different diets was similar, and there was no significant difference in the crude protein, fat and fiber contents of the meat $(p>0.05)$. The diets had no significant effects on magnesium, sodium, potassium and phosphorus contents of the meat. Crabs fed formulated diet had significantly higher calcium content of $20428.52 \pm 0.10 \mathrm{mg} / 100 \mathrm{~g}$, compared with the crabs fed with Trash Fish of $18541.83 \pm 0.10 \mathrm{mg} / 100 \mathrm{~g}(p<0.05)$. The pattern of mineral contents in both crabs was calcium $>$ phosphorus $>$ magnesium $>$ sodium $>$ potassium. This study suggested no negative effects of formulated diet on the meat quality. Therefore, formulated diet could be used for fattening of Land Crabs.
\end{abstract}

Keywords: Nutritional; Proximate; Mineral; Crustacean; Nigeria.

() 2020 JSR Publications. ISSN: 2070-0237 (Print); 2070-0245 (Online). All rights reserved. doi: http://dx.doi.org/10.3329/jsr.v12i3.44210 $\quad$ J. Sci. Res. 12 (3), 371-377 (2020)

\section{Introduction}

The crabs of the genus Cardiosoma are distributed within several kilometers away from the coast [1]. They were defined by Burggren and Mcmahon [2], as crabs that show significant behavioral, morphological, physiological and or biochemical adaptations permitting extended activities out of water. Cardiosoma are omnivorous crabs. They could feed on leaves, fruits and grasses collected near the vicinity of their burrows. These crabs will also feed on insects, worms and are sometimes cannibalistic. The population of this genus is heavily influenced by water temperature in areas where water temperature falls below $20{ }^{\circ} \mathrm{C}$ in winter; larval survival is affected [3]. The Land Crab, Cardiosoma armatum cohabit in the mangrove swamp of Abule-Agege Creek of Lagos where they are harvested by locals for domestic markets [4].

\footnotetext{
Corresponding author: tunjimoruf@gmail.com
} 
Trash fish (TF), which is considered as one of the best natural foods, has been widely used as a "standard food" for fattening crab in culture enterprises [5]. As the demand for natural feed increases while their availability decreases, the cost is expected to rise. Thus, replacement of TF with a cheaper practical diet for fish could alleviate the problem of low fish meal availability and high cost because the daily consumption of TF is more than 4 times that of formulated diet [6]. Effectively using formulated diet for fattening crab also reduces the requirements for TF. Moreover, TF can be greatly variable depending on the changing conditions during harvest, transportation, and storage; it also decays rapidly, leading to deteriorating water quality and increased risks of disease outbreaks [7]. In contrast, the greatest advantage of formulated diet is that it could be dependably supplied year-round, and the quality could also be guaranteed.

The time it takes to fatten a crab for market depends on the degree of fullness of the crab when started on the fattening regime, its size (the larger the crab, the longer it will take to fatten), the temperature and feed provided [8]. A crab fattening cycle typically takes from 14 to 60 days, during which time their protein content can increase from 8 to 15 percent [9]. The fast turnover of stock, relatively low operating costs and high survival in crab fattening systems makes them economically attractive, assuming enough "empty" crabs are available, either from farms or wild harvest [9].

With respect to the Land Crab, information exist on its nutritional compositions [10], morphometric characteristics [4] and Cardiosoma spp as an ecological indicator [11]. However, there is a dearth of information on its flesh characteristic with respect to feed consume. Therefore, the aim of this study was to investigate the dietary effects of natural and formulated diets on the meat quality of Land Crab, Cardiosoma armatum (Herklots, 1851). The study will establish if trash fish and formulated diet would provide similar meat quality with a view to effectively manage the resources for sustainable fisheries by crab farmers.

\section{Materials and Methods}

\subsection{Collection and acclimatization of experimental crab}

The experiment was conducted at the Department of Marine Sciences, University of Lagos. In early June 2018, 35 reared female crabs and 35 males were collected from the mangrove area of Lagos Lagoon (Latitude of $6^{\circ} 26^{\prime \prime} \mathrm{N}$ and $6^{\circ} 39^{\prime \prime} \mathrm{N}$ and Longitude of $3^{\circ} 29 " \mathrm{E}$ and $\left.3^{\circ} 50 " \mathrm{E}\right)$. The shores of the Lagos Lagoon and adjacent creeks are lined in undeveloped areas by mangrove swamps as described by Moruf et al. [12]. The mean body weights of the crabs were measured to be $80 \mathrm{~g}$. Considering the same feed consumption, the crabs were then selected and randomly stocked into eight small plastic tank (length $\times$ width $\times$ depth $=8 \mathrm{~m} \times 8 \mathrm{~m} \times 1.5 \mathrm{~m}$ ) at a 4 crabs per tank allowed to acclimatize for a week before the commencement of the experiment. The crabs were fed either with the Trash Fish (Sardinella aurita) or formulated diet once daily, the amount of which (dry weight) was approximately $2.2 \%$ of the total weight of crabs held in ponds. 
Over the period of the 3 months experiment, a water depth of $20 \mathrm{~cm}$ was maintained with $50 \%$ water in each pond exchanged every 3 days.

\subsection{Experimental diet}

The crabs were fed with two dietary treatments during the experiment. The trash fish (TF) was purchased from locals vendors in the better life market at Makoko Lagos. The formulated diet was produced by grinding the dry ingredients (Table 1) in a commercial machine with a $1 \mathrm{~mm}$ screen. The meal obtained was mixed with soya oil and water in a horizontal mixer (Mainca @ RM-90-135, USA) until the consistency was suitable for pelleting. The mixture was then extruded through a $3 \mathrm{~mm}$ die in a grinder. Pellets were steamed for $15 \mathrm{~mm}$ and stored at $20^{\circ} \mathrm{C}$ before use [13].

Table 1. Percentage composition of composition of the formulated diet for fattening land crab.

\begin{tabular}{lc}
\hline Ingredients & $\%$ \\
\hline Fish meal $(72 \%)$ & 30.00 \\
Fish meal $(65 \%)$ & 20.32 \\
Soybean meal & 20.00 \\
Wheat bran & 14.50 \\
Indomie & 15.00 \\
Vitamin- Mineral mix & 0.08 \\
Soybean oil & 0.10 \\
\hline
\end{tabular}

\subsection{Data Collection and analytical procedures}

At the end of the three (3) months experiment, the surviving crabs from each dietary treatment were then randomly sampled (six from each replicate), and their wet weights were determined. The crabs were then carefully dissected to remove the muscle tissues (meat) from all the body parts. The specimens were dried at $105{ }^{\circ} \mathrm{C}$ and homogenized. The analysis of the moisture, ash, protein, fat and carbohydrate contents was determined using the methods described by the AOAC [14] method using Soxhlet apparatus. For the mineral elements determination, the samples were digested in $\mathrm{HNO}_{3} / \mathrm{HCl}$. Thereafter some metal parameters namely $\mathrm{Ca}, \mathrm{P}, \mathrm{Mg}, \mathrm{Na}, \mathrm{Fe}, \mathrm{Mn}$ and $\mathrm{K}$ were measured by a Varian Spectra Atomic absorption spectrophotometer (AAS), Buck Scientific 210 GVP model following the reported procedure [15].

\subsection{Statistical analysis}

Mean and standard Error were derived from data obtained and subjected to analysis of variance (ANOVA), Pearson Correlation Coefficient at significant level of $\mathrm{P} \leq 0.05$. 


\section{Results and Discussion}

\subsection{Proximate}

The proximate composition including moisture, protein, fat, ash etc., are considered as good indicators of nutritional quality of an organism. The meat proximate composition of the crab fed Trash Fish (TF) and formulated diet is shown in the Table 2. The percentage moisture content in meat of the crabs fed with TF contained substantially higher moisture content $(73.13 \pm 0.10 \%)$ than the crabs fed with formulated diet $(69.29 \pm 0.90 \%)$. However, higher crude protein $(73.58 \pm 0.15 \%)$ and crude fat $(7.45 \pm 0.32 \%)$ contents were detected in the meat of the crabs fed with formulated diet as compared to crude protein $(65.03 \pm 0.21 \%)$ and crude fat $(7.21 \pm 0.18 \pm 0.32 \%)$ contents of meat in crabs fed with TF but the differences were not significant $(\mathrm{P}>0.05)$. The crude fiber in meat of the crabs fed with $\mathrm{TF}$ and that fed with formulated diet were $0.2 \pm 0.23 \%$ and $0.25 \pm 0.21 \%$ respectively. The total ash $(16.24 \pm 0.99 \%)$ and nitrogen free extract $(11.31 \pm 0.12 \%)$ contents of meat of the crabs fed with TF were significantly higher $(P<0.05)$ than the content of the ash $(13.61 \pm 0.10 \%)$ and nitrogen free extract $(5.08 \pm 0.84 \%)$ of meat of the crabs fed with formulated diet. The crude protein contents of crab meat in this study were higher than the $18.5 \%$ of the Chinese mitten crab, Eriocheir sinensis [16]. The higher protein and lipid content of the meat also reveals involvement in energy production at cellular level [17]. However, the quantities of these constituents may vary considerably within and between the species, size, sex, sexual condition, feeding season, molting stage, processing method etc., [18-20]. Most of the $p$ values were higher than 0.05, indicating that the effect of different diets on proximate composition of the meat of $C$. armatum was limited, which was in accordance with the results from [21]. It is also generally similar to other crab species, such as the mud crab, Scylla serrata [22]; the blue crab, Callinectes sapidus [23]; the blue swimmer crab, Protunus pelagicus [24]; and the Chinese mitten crab, E. sinensis $[5]$.

Table 2. Proximate Composition (Dry Matter Basis) of the Meat of Land Crab, Cardiosoma armatum Fed with Trash Fish and Formulated Diets.

\begin{tabular}{lll}
\hline Parameter $(\%)$ & Trash Fish (Natural Diet) & Formulated Diet \\
\hline Moisture & $73.13 \pm 0.10^{\mathrm{a}}$ & $69.29 \pm 0.90^{\mathrm{a}}$ \\
Protein & $65.03 \pm 0.21^{\mathrm{a}}$ & $73.58 \pm 0.15^{\mathrm{a}}$ \\
Crude fat & $7.21 \pm 0.18^{\mathrm{a}}$ & $7.45 \pm 0.32^{\mathrm{a}}$ \\
Crude fiber & $0.2 \pm 0.23^{\mathrm{a}}$ & $0.25 \pm 0.21^{\mathrm{a}}$ \\
Total ash & $16.24 \pm 0.99^{\mathrm{a}}$ & $13.61 \pm 0.10^{\mathrm{b}}$ \\
Nitrogen free extract NFE & $11.31 \pm 0.12^{\mathrm{a}}$ & $5.08 \pm 0.84^{\mathrm{b}}$ \\
\hline Keys: Mean \pm Standard Error; Values with different superscripts across row are significantly different at $(\mathrm{P}<0.05)$
\end{tabular}

\subsection{Mineral content}

The result of the mineral contents (Table 3 ) obtained in the present investigation clearly demonstrate that, the proportion of calcium and phosphorus were dominating over magnesium, sodium and potassium contents in both the crabs fed with TF and the crabs 
fed with formulated diet. The mineral contents in $\mathrm{mg} 100 \mathrm{~g}^{-1}$ of the meet of the crabs fed TF were Ca (18541.83 \pm 0.10$), \mathrm{P}(1572.57 \pm 0.10), \mathrm{Mg}(486.69 \pm 0.10), \mathrm{Na}(150.35 \pm 0.10)$ and $\mathrm{K}(112.32 \pm 0.10)$, while the mineral content in $\mathrm{Mg} 100 \mathrm{~g}^{-1}$ of the meat of crabs fed with formulated diet were $\mathrm{Ca}(20428.52 \pm 0.10), \mathrm{P}(1612.62 \pm 0.10), \mathrm{Mg}(337 \pm 0.10), \mathrm{Na}$ $(128.14 \pm 0.10)$ and $\mathrm{K}(100.81 \pm 0.10)$. The pattern of mineral contents in both crabs was $\mathrm{Ca}$ $>\mathrm{P}>\mathrm{Mg}>\mathrm{Na}>\mathrm{K}$. With the exception of $\mathrm{Ca}$ and $\mathrm{Na}$, both diets appeared to have no significant effects $(p>0.05)$ on the mineral content of the meat of Cardiosoma armatum. The resultsof the mineral content in this study is similar to previous reports on the same crab species sampled from other location [10]. Also, it is confirmed to be similar to that of other shellfish species, such as the blue crab, Callinectes sapidus [23]; the periwinkle, Tympanotonus fuscatus [25]; the Guinean Mantis Shrimp, Squilla aculeata calmani [26]; and the Lagoon crab, Callinectes amnicola [27].

Table 3. Mineral Content in Meat of the Land Crab, Cardiosoma armatum Fed with Trash Fish and Formulated Diets.

\begin{tabular}{lll}
\hline Parameter $(\mathrm{mg} / 100 \mathrm{~g})$ & Trash Fish $($ Natural Diet) & Formulated Diet \\
\hline Calcium, $\mathrm{Ca}$ & $18541.83 \pm 0.10^{\mathrm{a}}$ & $20428.52 \pm 0.10^{\mathrm{b}}$ \\
Magnesium, $\mathrm{Mg}$ & $486.69 \pm 0.10^{\mathrm{a}}$ & $337 \pm 0.10^{\mathrm{a}}$ \\
Sodium, $\mathrm{Na}$ & $150.35 \pm 0.10^{\mathrm{a}}$ & $128.14 \pm 0.10^{\mathrm{b}}$ \\
Potassium, $\mathrm{K}$ & $112.32 \pm 0.10^{\mathrm{a}}$ & $100.81 \pm 0.10^{\mathrm{a}}$ \\
Phosphorus, $\mathrm{P}$ & $1572.57 \pm 0.10^{\mathrm{a}}$ & $1612.62 \pm 0.10^{\mathrm{a}}$ \\
\hline Keys: Mean \pm Standard Error; Values with different superscripts across row are significantly different at $(\mathrm{P}<0.05)$
\end{tabular}

\subsection{Correlation between proximate and mineral composition}

The correlation matrix showed some important relationships between the proximate and Mineral composition analyzed. Table 4 shows the correlation matrix for crabs fed with TF in which crude protein showed strong positive relationship to phosphorus $(r=0.87)$ but weak positive relationship to magnesium $(r=0.24)$. Crude fiber had positive relationship with all the minerals except phosphorus $(r=-0.96)$ while ash was positively correlated to all the minerals. According to Lawal-Are et al. [26], ash is a measure of the mineral content of food item, thus indicates that the crab meat is a good source of minerals.

The correlation matrix for the crabs fed formulated diets is presented in Table 5. Positive correlation occur between crude protein and phosphorus $(r=0.84)$. Similar relationship was exhibited by crude fiber with calcium $(r=0.69)$, magnesium $(r=0.67)$, sodium $(r=0.97)$ and potassium $(r=0.81)$ with significance at the 0.05 level. The correlation analyses suggest that ash content will positively affect all the minerals analyzed, making these nutrients available. This is in agreement with Lawal-Are et al. [26] who reported perfect positive relationships between proximate and mineral components for fillet and whole body of Squilla aculeata calmani. 
Table 4. Correlation between proximate composition and mineral contents of Cardiosoma rmatum fattened with trash fish (natural diet).

\begin{tabular}{|c|c|c|c|c|c|c|c|c|c|c|c|}
\hline & Moisture & Crude protein & Crude fat & Crude fiber & Ash & $\mathrm{NFE}$ & $\mathrm{Ca}$ & $\mathrm{Mg}$ & $\mathrm{Na}$ & $\mathrm{K}$ & $\mathrm{P}$ \\
\hline Moisture & 1 & & & & & & & & & & \\
\hline Crude Protein & 0.87 & 1 & & & & & & & & & \\
\hline Crude fat & 0.66 & 0.62 & 1 & & & & & & & & \\
\hline Crude fiber & -0.93 & -0.84 & -0.70 & 1 & & & & & & & \\
\hline Total ash & -0.96 & -0.97 & -0.76 & 0.89 & 1 & & & & & & \\
\hline NFE & -0.82 & -0.98 & -0.61 & 0.78 & 0.92 & 1 & & & & & \\
\hline $\mathrm{Ca}$ & -0.78 & -0.90 & -0.43 & 0.82 & 0.80 & 0.92 & 1 & & & & \\
\hline $\mathrm{Mg}$ & -0.07 & 0.24 & 0.09 & 0.25 & 0.21 & -0.26 & 0.06 & 1 & & & \\
\hline $\mathrm{Na}$ & -0.64 & -0.46 & -0.38 & 0.79 & 0.48 & 0.42 & 0.64 & 0.73 & 1 & & \\
\hline $\mathrm{K}$ & -0.62 & -0.40 & -0.20 & 0.76 & 0.43 & 0.33 & 0.59 & 0.74 & 0.93 & 1 & \\
\hline $\mathrm{P}$ & 0.82 & 0.73 & 0.62 & -0.96 & 0.79 & -0.68 & -0.78 & -0.35 & -0.77 & -0.80 & 1 \\
\hline
\end{tabular}

Table 5. Correlation between proximate composition and mineral contents of Cardiosoma armatum fattened with formulated diet.

\begin{tabular}{|c|c|c|c|c|c|c|c|c|c|c|c|}
\hline & Moisture & Crude protein & Crude fat & Crude fiber & Ash & NFE & $\mathrm{Ca}$ & $\mathrm{Mg}$ & $\mathrm{Na}$ & $\mathrm{K}$ & $\mathrm{P}$ \\
\hline Moisture & 1 & & & & & & & & & & \\
\hline Crude protein & -0.97 & 1 & & & & & & & & & \\
\hline Crude fat & 0.81 & -0.55 & 1 & & & & & & & & \\
\hline Crude fiber & 0.21 & 0.14 & 0.75 & 1 & & & & & & & \\
\hline Total ash & -0.67 & 0.38 & -0.98 & -0.86 & 1 & & & & & & \\
\hline NFE & 0.41 & -0.06 & 0.87 & 0.98 & -0.95 & 1 & & & & & \\
\hline $\mathrm{Ca}$ & 0.85 & -0.61 & -0.96 & 0.69 & 0.99 & 0.82 & 1 & & & & \\
\hline $\mathrm{Mg}$ & 0.87 & -0.64 & -0.95 & 0.67 & 0.99 & 0.80 & 0.99 & 1 & & & \\
\hline $\mathrm{Na}$ & 0.45 & -0.11 & -0.96 & 0.97 & 0.89 & 0.99 & 0.85 & 0.84 & 1 & & \\
\hline $\mathrm{K}$ & 0.75 & -0.47 & -0.99 & 0.81 & 0.99 & 0.91 & 0.99 & 0.98 & 0.93 & 1 & \\
\hline $\mathrm{P}$ & 0.21 & 0.84 & -0.86 & -0.80 & 0.75 & 0.98 & 0.69 & 0.69 & 0.97 & 0.81 & 1 \\
\hline
\end{tabular}

\section{Conclusion}

The study found that no significant difference between trash fish (Sardinella aurita) and formulated feed was shown in the meat quality of Land Crab, Cardiosoma armatum. Therefore, the formulated diet developed by our laboratory could be used to totally replace the trash fish for fattening the crab as this will not affect the meat quality. Various indices measured in the present study also suggest that the meat of the crab is a rich source of nutrients and essential minerals, good for human health.

\section{References}

1. S. L. Gilchrist, Appendix Natural Histories of Selected Terrestrial Crabs, in Biology of the Land Crabs, ed. W. W. Burggren et al. (Cambridge University Press, New Zealand, 1998), pp. 383-390.

2. W. W. Burggren and B. R. McMahon, Circulation, in Biology of the Land Crabs, ed. W. W. Burggren et al. (Cambridge University press, New Zealand, 1988) pp. 298-332. https://doi.org/10.1017/CBO9780511753428.010

3. C. G. Bookhout and J. D. Costlow, Helgolander Wissenschaftliche Meeresuntersuchungen 20 , 435 (1970). https://doi.org/10.1007/BF01609919

4. A. O. Lawal-Are, R. O. Moruf, K. L. Akubueze, and O. Adewole, Nigerian J. Agri., Food Environ. 15, 83 (2019). 
5. L. Shao, C. Wang, J. He, X. Wu, and Y. Cheng, J. Aq. Food Product Technol. 23, 59 (2014). https://doi.org/10.1080/10498850.2012.694583

6. K. O. M. Millamena and J. P. Bangcaya, Asian Fish. Sci. 14, 153 (2001). https://doi.org/10.1023/A:1024188507215

7. X. G. Wu, Y. X. Cheng, L. X. Sui, X. Z. Yang, T. Z. Nan, and J. Q. Wang, Aquaculture Res. 38, 1459 (2007). https://doi.org/10.1111/j.1365-2109.2007.01728.X

8. M. K. Anil and C. Suseelan, Experimental Fattening of the Green Mud Crab Scylla oceanica (Dana), in Perspectives in Mariculture, ed. N. G. Menon et al. pp. 95-110 (2001).

9. R. F. Agbayani, D. D. Baliao, G. P. B. Samonte, R. E. Tumaliuan, and R. D. Caturao, Aquaculture 91, 223 (1990). https://doi.org/10.1016/0044-8486(90)90190-X

10. I. O. Elegbede and H. A. Fashina-Bombata, Poultry, Fisheries Wildlife Sci. 2, 110 (2013).

11. I. O. Elegbede and A. O. Lawal-Are, Poultry, Fisheries Wildlife Sci. 3, 12 (2013). https://doi.org/10.4172/2375-446X.1000139

12. R. O. Moruf, O. D. Bolaji, and A.O. Lawal-Are, Egyt. J. Aqua. Bio. Fish. 22, 87 (2018). https://doi.org/10.4314/jasem.v22i12.5

13. P. H. Truong, A. J. Anderson, P. B. Mather, B. D. Paterson, and N. A. Richardson, Aquaculture Res. 39, 1778 (2008). https://doi.org/10.1111/j.1365-2109.2008.02056.x

14. AOAC (Association of Official Analytical Chemist) $8^{\text {th }}$ Edition (Arlington, 2007).

15. J. Santoso, Y. Yoshie-Stark, and T. Suzuki, Bull. Aq. Products Technol. 9, 1 (2006).

16. L. Z. Yang, S. S. Chen, Y. H. Qu, and K. Masaki, J. Shanghai Fisheries Univ. 16, 92 (2007).

17. A. O. Lawal-Are, R. O. Moruf, D. A. Junaid, and M. O. Oke, Food Environ. Safety 17, 332 (2018).

18. R. Nargis, Bangl. J. Sci. Ind. Res. 41, 219 (2006). https://doi.org/10.3329/bjsir.v41i3.292

19. R. Rosa and M. L. Nunes, Deep-Sea Res. 50, 119 (2003). https://doi.org/10.1016/S0967-0637(02)00147-4

20. M. Shafiq, S. Firdous, Q. Ifan, S. J. Khan, and A. Qadir, J. Sci. Res. 11, 365 (2019). https://doi.org/10.3329/jsr.v11i3.40493

21. O. T. Omotosho, Afric. J. Appl. Zool. Environ. Biol. 7, 68 (2005).

22. D. F. Tan, G. X. Wu, Y. X., Lin, and W. F. Qiu. Fujian Normal Univ. Nat. Sci. 16, 79 (2000).

23. N. Gokoglu and P. Yerlikaya, Food Chem. 80, 495 (2003). https://doi.org/10.1016/S0308-8146(02)00318-7

24. X. G. Wu, B. Zhou, Y. Cheng, C. Zeng, C. Wang, and L. Feng, J. Food Comp. Anal. 23, 154 (2010). https://doi.org/10.1016/j.jfca.2009.08.007

25. R. O. Moruf and V. F. Akinjogunla J. Experiment. Res. 6, 35 (2018).

26. A. O. Lawal-Are, R. O. Moruf, and O. A. Afolayan, Albanian J. Agric. Sci. 17, 160 (2018).

27. R. O. Moruf, A. O. Saba, J. Chukwu-Osazuwa, and I. O. Elegbede, Agricultura 102, 200 (2019). 